\author{
J.BRADFORD DELONG \\ University of California, Berkeley
}

\title{
Financial Crises in the 1890s and the 1990s: Must History Repeat?
}

THE 1990S HAVE seen three large international financial crises shake the world economy: the collapse of western Europe's Exchange Rate Mechanism (ERM) in the fall of 1992, the collapse of the Mexican peso in the winter of 1994-95, and the East Asian financial crisis of 1997-98. Other crises late in the decade, in Brazil and Russia, did not develop the scope or reach of these three, even though observers and central bankers at the time feared that their consequences could become even worse. ${ }^{1}$

The European crisis resulted from a standoff in economic policy between the chancellor and the central bank of Germany, Europe's largest economy, over how to finance the enormous reconstruction expenditures required by the absorption of the former East Germany. ${ }^{2}$ The standoff produced a monetary policy that was too tight for the rest of western Europe (and, indeed, too tight for Germany). Speculators bet that such tight monetary policies in other western European countries would prove unsustainable, and that political pressures in those countries to devalue their currencies against the deutsche mark would in the end prove irresistible. Speculating on the prospective collapse of the ERM thus became a classic one-way bet. Only even tighter monetary policies for the rest of western Europe could have provided an incentive not to speculate on the prospective rise of the mark, yet such policies had an even smaller chance of being politically sustainable in the long run. ${ }^{3}$ In northern Europe, at least, the crisis looked self-fulfilling and self-generated: it was only the belief that

1. See Greenspan (1998).

2. Sinn and Sinn (1992).

3. Eichengreen and Wyplosz (1993). 
macroeconomic policies would prove unsustainable in the end that made them inappropriate; in the absence of that belief, policies in those countries would in all likelihood have been sustainable and appropriate. ${ }^{4}$

The second crisis, the collapse of the Mexican peso in the winter of 1994-95, did follow an episode in which monetary policy had been wildly, unsustainably expansionary throughout 1994. But this episode had been transitory, linked to the septennial redistribution of wealth and political favors by the corrupt Institutional Revolutionary Party as the outgoing president gave way to his chosen successor. Such a transitory burst of monetary expansion would not normally have been thought to have a significant impact on expectations. And whether the peso was overvalued in real terms as a result of this expansion depended on the long-run rate of flow of capital from the United States to Mexico. A high rate of inflow would require a relatively appreciated peso. Indeed, the two years leading up to the crisis had seen foreign exchange markets place at least as much upward as downward pressure on the peso's dollar value. ${ }^{5}$

The third crisis, the Asian crisis of 1997-98, has so far proved impossible to fit neatly into the category of financial crises generated by macroeconomic instability. That crisis hit countries where the economic fundamentals were sounder and macroeconomic policies far less subject to criticism than was the case in either of the other two major crises. Their economies bore next to no resemblance to the picture painted by Paul Krugman of an economy vulnerable to currency crisis because it is pursuing unsustainable macroeconomic policies. ${ }^{6}$ The economies of the Asian Pacific Rim hit by the crisis-Indonesia, Malaysia, Singapore, South Korea, Taiwan, and Thailand-had, as a group, achieved the fastest sus-

4. As Richard Cooper points out in his comment, macroeconomic policy in parts of southern Europe had seriously unsustainable features that made likely a classic macroinstability-generated crisis in the manner of Krugman (1979).

5. See DeLong, DeLong, and Robinson (1996). Throughout 1993 and 1994 all segments of American political and economic opinion agreed that capital flows to Mexico from the United States would be large and durable. Observers differed only in their characterization of those flows: the left saw them as the source of imperialistic recolonization, the center as an opportunity to jumpstart the Mexican economy and reduce by a decade the time needed for industrialization, and the right as a sinister plot to steal the jobs of American workers for the benefit of Treasury Secretary Robert Rubin and his friends at Goldman Sachs. Such expectations of large capital inflows generated relatively high projected real exchange values for the peso.

6. Krugman $(1979,1996)$. 
tained rate of economic growth ever seen in any group of countries in any era. ${ }^{7}$ Yet once investors in New York and elsewhere had decided that they had invested too large a share of their portfolios in Asia, the rapid shift in opinion and in capital flows had the same consequences as in Mexico and western Europe previously. ${ }^{8}$

Practically every observer who commented on these successive waves of crises saw them as symptomatic of deep troubles in the structure of global finance. All agreed that if the financial system were properly structured and properly managed, we would not see so many severe crises following wave upon wave. However, diagnoses of the precise flaws in global financial organization turned out to be all over the map; in the aggregate they were, in Barry Eichengreen's polite words, "contradictory and mutually incompatible." 9

For example, diagnoses were contradictory and mutually incompatible with respect to the role played by inappropriate exchange rate flexibility (or inappropriate exchange rate fixity) in the crisis. Some saw the fundamental flaw in the advice of the International Monetary Fund (IMF) to emerging market governments to allow their currencies to depreciate during the crisis rather than maintain the previous parity against the dollar no matter what the cost in terms of higher domestic interest rates. ${ }^{10}$ Yet others saw the fundamental flaw in the IMF's advice to these governments to raise interest rates to reduce the magnitude of the fall in their currencies' value. ${ }^{11}$

Opinions about the proper role and amount of external assistance were no less contrary. Some saw the IMF's willingness to provide assistance to the distressed economies - albeit at high interest rates and accompanied by drastic changes in fiscal policy and promised changes in regulatory and supervisory policy - as itself the fundamental error. Proponents of this view have argued that it is the availability of IMF support that causes gov-

\section{Maddison (1995).}

8. Goldstein (1998); Radelet and Sachs (1998).

9. Eichengreen (1999, p. 1).

10. "Mr. Rubin and Currency Stability," Wall Street Journal, July 1, 1998, p. A-18; "Sex, Lies, and the IMF," Wall Street Journal, September 15, 1998, p. A-22; David Malpass, "Asia's Reckoning: A Weak Economy Needs a Strong Currency," Wall Street Journal, June 17, 1998, p. A-16.

11. Radelet and Sachs (1998); Sachs (1998). Note that the only point of agreement with the positions referenced in the previous footnote is that the crises were somehow the IMF's fault. 
ernments to pursue rash and unsustainable policies, because such support ex post minimizes the economic cost. Thus provision of IMF loans to Mexico in the 1994-95 crisis led investors in East Asia in 1996-97 to expect that the IMF would bail them out, and the resulting moral hazard induced the overlending that was at the root of the 1997-98 crisis. $^{12}$

But others took the opposite position, namely, that the flaw in the handling of the crisis was that the IMF did not lend enough: that larger loans with less stringent conditions for longer periods would have allowed the troubled economies to largely sterilize the panicked wave of capital outflows. They could have waited until once again foreign investors were impressed with their rapid trend growth rates and high rates of physical capital investment, human capital investment, and technology acquisition. The oldest rule for lenders of last resort, after all, is to lend freely at a penalty rate on security that is acceptable in normal times. ${ }^{13}$ East Asian governments and businesses had ample security and collateral that would have been acceptable in normal times. Senior international agency officials claimed that Mexico's mid-1990s recession was worse than it might have been because the funds committed by the United States to dealing with the crisis - $\$ 12$ billion or so for one year-were smaller and lent for a shorter time than they should have been, because of political pressure from Senator Alfonse D'Amato (R-NY) and the rest of the Republican right. The same lesson may apply to East Asia.

Finally, some saw the foundations of the crisis in fundamental mistakes of long-run policy: the wrong institutions had been built, and growth would not resume without fundamental institutional reforms. Others, however, argued that it was premature to condemn Asia's institutions wholesale and demand fundamental reforms in financial systems that had fueled the region's unprecedented rate of economic growth. To these observers such a judgment seemed especially premature given economists' limited knowledge of what the appropriate structure of financial institutions really is, and given the international agencies' lack of experience in the field. ${ }^{14}$

It is clear that no conceivable amount of abstract argument-and no practical amount of contemporary evidence-is going to change many

12. George Shultz, William Simon, and Walter Wriston, "Who Needs the IMF?" Wall Street Journal, February 13, 1998, p. A-15; William Simon, "Abolish the IMF," Wall Street Journal, October 23, 1997, p. A-17.

13. Bagehot (1873).

14. Feldstein (1998) 
minds about Mexico 1994-95, East Asia 1997-98, or any subsequent international financial crises that may be coming down the pipeline in the next decade. There are three major points of disagreement: Are flexible exchange rates a help or a hindrance? Is IMF support in a crisis a cure or a cause? And does recovery and a resumption of capital flows require deep-rooted financial sector reforms to diminish corruption and improve transparency and corporate governance? The reason why contemporary evidence will fail to change many minds on these issues is that the critical points at issue all involve speculation about what would have happened under different policies. What if the IMF had lent more? What if it had lent less? What if it had imposed stricter conditions? What if it had been more lenient? And so on. Yet none of these counterfactual worlds are available for our inspection.

Thus it is here that economic history can be useful. For ours is not the first age of large-scale international capital flows, or of virulent international financial crises. We today live in what we might well call the second age of globalization. The first took place during the half-century before World War I, when free trade, free flows of capital, free migration, and the classical gold standard all gained increasing strength, and falling transport and communications costs knit the world economy together and fueled rapid growth up until the disaster of the world war. ${ }^{15}$

In this first era of globalization there was no IMF. There was little exchange rate variability (or at any rate far less than the world has seen recently). And financial market organization, as measured by the absence of corruption and of "crony capitalism," was certainly no better than it is today. Capital flows then were as large as capital flows are now relative to the size of their economies. And these flows were accompanied by frequent international financial crises: in the case of the United States, about once every eight years.

The historical experience reviewed below allows us to draw three conclusions:

- Large-scale financial market reform is not a prerequisite for recovery and a renewal of capital flows. The experience of the late nineteenth century indicates strongly that capital flows will renew-and at a rapid rate-

15. O'Rourke and Williamson (1999); Bordo, Eichengreen, and Kim (1998); Bordo, Eichengreen, and Irwin (1999). 
whether or not emerging markets reform their financial markets to reduce information asymmetries and thus make the playing field more level.

- The availability of IMF-funded rescue packages in financial crises is not a decisive factor causing today's crises. Back before World War I there were no international rescue packages, yet there were crises. Whether or not the availability of rescue packages has played a role in aggravating crises is a much harder question: it is, after all, hard to prove a negative. But there is certainly no evidence that even the worst of the recent international financial crises have been more virulent than the worst crises of the past. ${ }^{16}$

-Fixed exchange rate systems played an important role in speeding recovery before World War I. Once the peak of the crisis had passed, all actors expected a recovery to a fixed parity, and this made for waves of stabilizing, not destabilizing, speculation. The relevance of this point today is not clear: it is difficult in the current political context to create an exchange rate that is not only fixed but credibly fixed. But a look back at history does reinforce the hollowing out of intermediate positions on exchange rate regimes that has been taking place over the past several years. In today's climate it may be that the benefits of fixed rate systems for handling financial crises can only be accomplished by dollarization (or perhaps euroization, or yenization).

\section{The First Era of Globalization}

\section{Trade Flows Then and Now}

It is increasingly commonplace to say that the world economy today has become more integrated and more interconnected than ever before. Along most dimensions, the present integration of national economies is judged to surpass even that of the peak years of international integration just before World War I. ${ }^{17}$

16. Bordo and Schwartz (1996) make the best attempt thus far to compare the magnitude of international financial crises across eras. Bordo and Eichengreen's (1999) analysis of their data suggests that international financial crises now are less common than in the past, and that the worst crises then were at least of the same magnitude as the worst crises now, but that the average crisis then had smaller effects on the real economy than the average crisis now.

17. Bordo, Eichengreen, and Irwin (1999); O'Rourke and Williamson (1999). 
Figure 1. United States: Merchandise Trade, 1869-1997

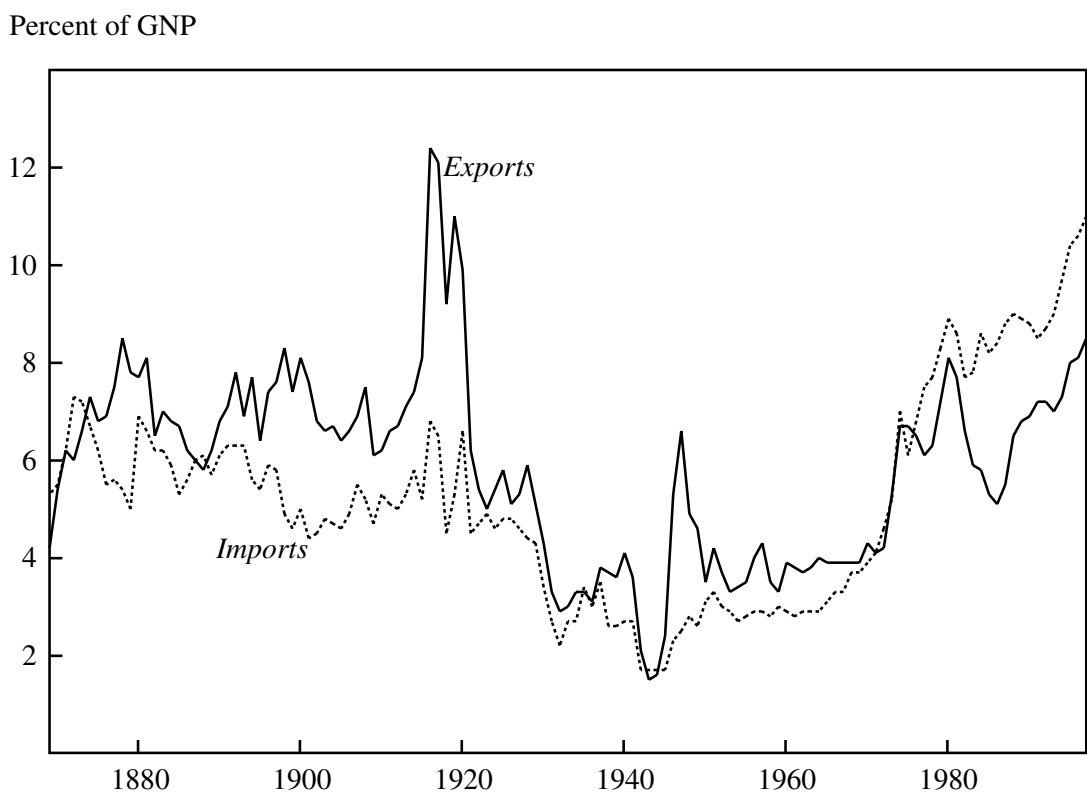

Source: Bordo, Eichengreen, and Irwin (2000).

As figure 1 shows, in recent years U.S. trade as a share of GNP has risen above the levels reached during the pre-World War I years of the classical gold standard. ${ }^{18}$ Throughout much of that period, countries imposed tariff barriers that, although low by the standards of previous eras, were still high when measured as shares of the values of staple commodities. ${ }^{19}$ These barriers, together with high transport costs, kept the law of one price from operating: in 1870 the prices of agricultural staples in Great Britain

18. Moreover, trade in services, which is not counted in most standard long-run comparisons, is a much larger share of total trade today than it was before 1914 .

19. Free-trade Great Britain aside, pre-World War I tariff rates were on the order of 20 percent ad valorem for the major European economies, and on the order of 40 percent for the United States. See Bairoch (1993) and Bairoch and Kozul-Wright (1998), cited in Bordo, Eichengreen, and Irwin (1999). 
were some 50 percent higher than in the United States, and the covariance of year-to-year price movements was not extraordinarily high. ${ }^{20}$

Reinforcing the somewhat greater relative importance of international trade today is the rise of the multinational enterprise. During the first era of globalization it was extremely difficult for company headquarterswhether in London, New York, or Chicago — to specify production and to control operations across the oceans. Today, by contrast, what is demanded in New York on Tuesday can be known in the factories in Thailand on Wednesday, and produced on Thursday. The implications of this increasing reach of corporate control for how we should think about international economic integration are not clear. But overseas investment by multinationals today implies a much greater degree of control and integration of production than did overseas investment by free-standing companies a century ago. And this is not a change that should be ignored. ${ }^{21}$

\section{International Finance Then and Now}

Although the world today is thus more globalized than ever before as far as trade is concerned, it is still less globalized than it was before 1914 as far as the magnitude of net international capital flows is concerned. Some analysts point out that international capital flows before World War I were confined to a relatively small group of industries and sectors. Capital flowed across national borders to lend to governments; to build ports, sewers, and gas lines; to build railroads and mines. But by and large, until the last years before World War I, it was nearly unheard of for capital to flow across national borders to make a portfolio investment in a manufacturing or service company headquartered in another country. ${ }^{22}$

Michael Bordo, Barry Eichengreen, and Jongwoo Kim interpret this concentration of investment in "tangible and therefore relatively transparent assets" as showing how information asymmetries and perverse incentives-crony capitalism-restricted capital flows and made the world capital market before World War I less open than today. ${ }^{23}$ This argument, however, does not seem to take adequate account of the key role played

20. O'Rourke and Williamson (1999). These authors calculate that price gaps narrowed sharply and covariances increased rapidly throughout the classical gold standard period.

21. See Vernon (1971).

22. Grossman and DeLong (forthcoming).

23. Bordo, Eichengreen, and Kim (1998). 
by railroads as the transportation infrastructure of the era: the equivalent today of air transport, rail transport, and road transport all rolled into one. The number of sectors in which foreign investment was concentrated back before World War I was indeed relatively small. The share of those sectors in total turn-of-the-last-century investment was not. Foreign investors poured funds into railroads not because of their lower informational risk, but because that was where all the action was.

Moreover, focusing on international principal-agent and asymmetric information problems today ignores the fact that domestic financial market imperfections appear to have been much larger a century ago, especially in Britain. British dividend yields were markedly (between 2 and 4 percentage points) higher before World War I than they have been since, without any clear fundamental reason: neither greater risk, nor higher interest rates, nor sufficiently lower average rates of dividend growth. British investors before World War I appear to have been fearful of equities. They preferred to commit their savings to foreign ventures in infrastructure industries like railroads and in loans to governments rather than risk their money in what would likely have been less risky investments in domestic British manufacturing. ${ }^{24}$ And it is the relative magnitude of asymmetric information and principal-agent problems between domestic and foreign investments that is relevant.

Flows of net international investment had built up, by the eve of World War I, to net capital positions of astonishing magnitude. Great Britain in 1913 had net overseas assets of perhaps 47 percent of total domestic wealth. An equivalent net overseas asset position for the United States today, relative to GDP, would be about $\$ 14$ trillion. At its peak, nearly 10 percent of British national product was earned by British capital invested abroad. ${ }^{25}$ And Britain, although the largest holder of net overseas assets relative to national product, was not an exceptional case. French and Dutch citizens held between a quarter and a third of their wealth overseas as well.

The large net international capital flows of the pre-World War I period meant that the association between domestic saving and investment rates was weaker then than it is today. As figure 2 shows, in the generation after World War II a 1-percentage-point rise in a country's national saving rate

24. DeLong and Grossman (1993).

25. Edelstein (1994, p. 173). 
Figure 2. Coefficients from Regressions of National Investment on National Saving Rates ${ }^{\mathrm{a}}$

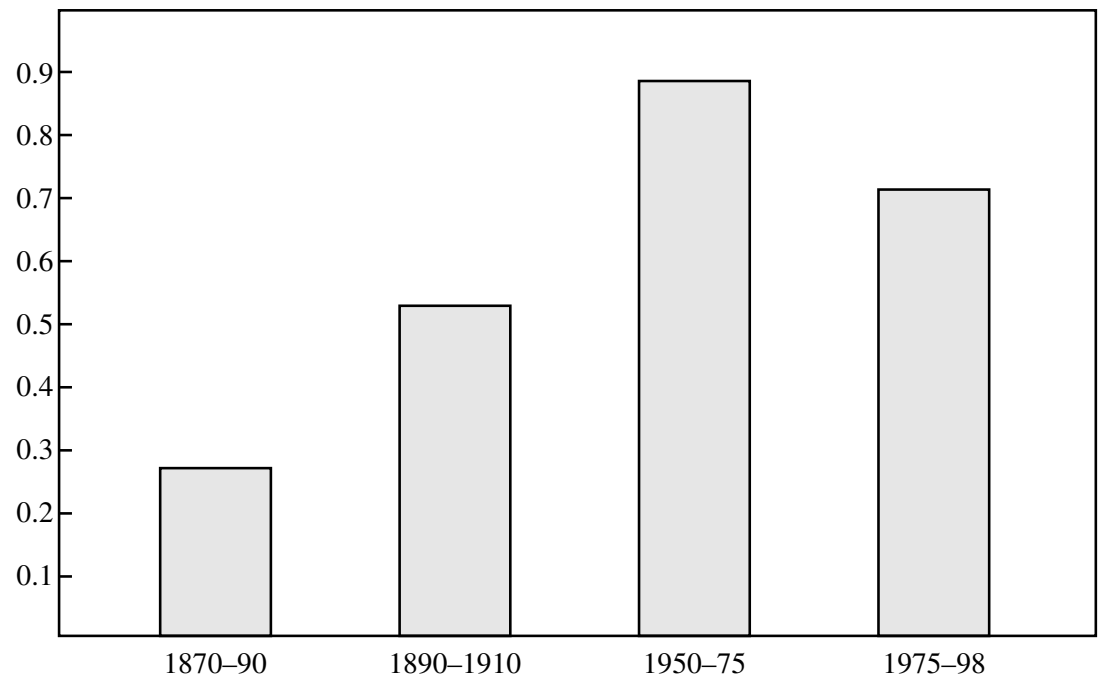

Source: Taylor (1996).

a. Bars represent the effect on investment of a 1-percentage-point rise in the saving rate. The regression contains no additional right-hand-side variables.

was associated with a 0.9-percentage-point rise in its national investment rate; for the most recent generation the figure is slightly lower, at 0.7 percentage point. By contrast, in the generation before World War I, a 1-percentage-point rise in the saving rate was associated with only a 0.5 -percentage-point increase in the investment rate, and in the generation after the Civil War the association was only 0.3 percentage point. ${ }^{26}$ The Feldstein-Horioka observation of a close correlation between national saving and investment rates holds remarkably well today, but it was not a characteristic of economies before World War I.

These enormous overseas asset positions were not built up smoothly, as figure 3 shows. Net foreign investment by Britons, for example, reached a high of nearly 8 percent of GDP in the early 1870s before falling to less than 1 percent of GDP in 1877, and similar cycles are observed over the succeeding forty years. Measured in percentage points of GDP, these cyclical swings in net foreign investment had approximately twice as large a

26. Taylor (1996); Feldstein and Horioka (1980). 
Figure 3. United Kingdom: Net Outward Foreign Investment, 1850-1913

Percent of GDP

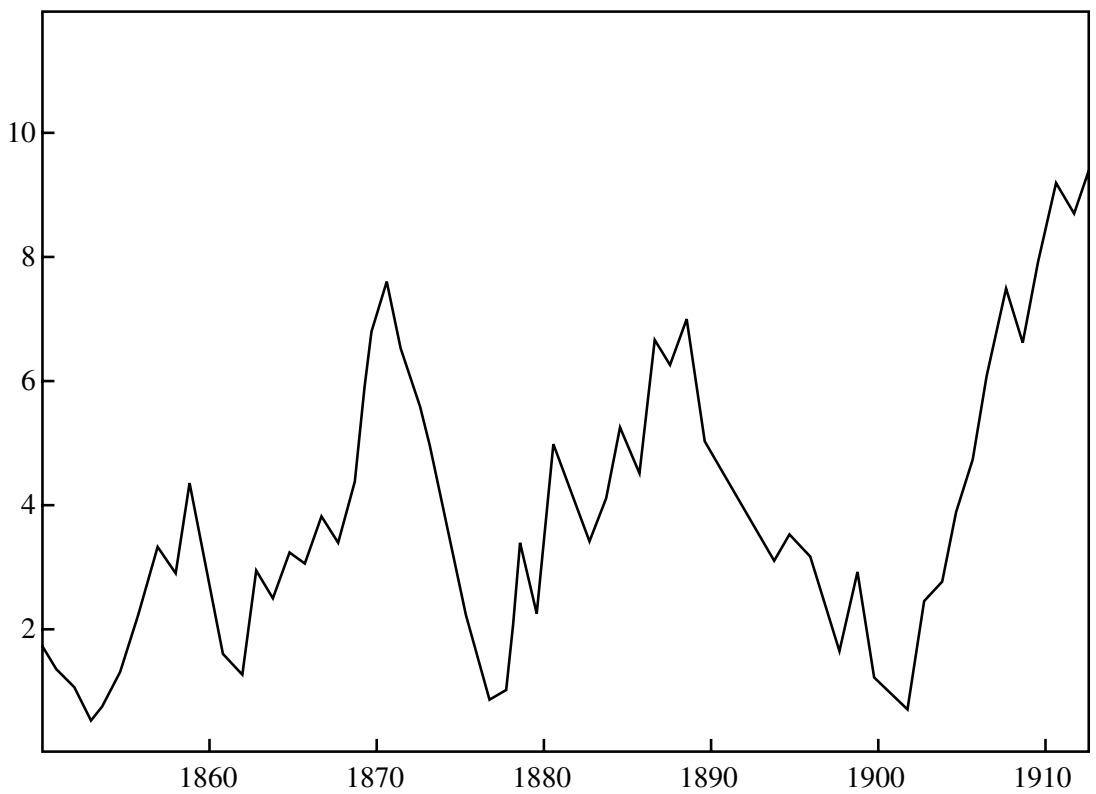

Source: Edelstein (1994).

magnitude as, and an inverse correlation with, pre-World War I cyclical swings in British domestic investment. ${ }^{27}$

It is worth pointing out that none of the fundamental explanations for the large swings in overseas investment rates associated with recent financial crises apply to the large swings in British overseas investment before 1914. The receiving countries, which were overwhelmingly in what Arthur Lewis called the temperate regions of European settlement-Argentina (and Uruguay), Australia, Canada, New Zealand, and the United States ${ }^{28}$ had stable governments: there were no swings from democracy to populist dictatorship to internationalist oligarchy and back. The receiving countries did not (with the exception of Argentina) adopt perverse inflationary macroeconomic policies. There were no sudden recognitions by

27. Edelstein (1994).

28. Lewis (1938). 
foreign investors that overseas governments and courts were corrupt. There were no major supply shocks to derange the world pattern of production and comparative advantage. Yet the share of its national product that British investors thought it optimal to commit to overseas investments repeatedly swung from 3 percent to 8 percent of GDP and back again.

\section{How Severe Were Pre-World War I Financial Crises?}

In the years after the U.S. Civil War, foreign capital flowed abundantly into the United States, financing perhaps half of the railroad boom of the late 1860 s and early 1870 s. And in 1873 came the first crash. The spectacular collapse of the Northern Pacific Railroad and the banking house of Jay Cooke and Company, in the aftermath of scandals involving the Union Pacific's Credit Mobilier, the Erie Railroad, and the attempt to corner the gold market, led to a rapid drying up of foreign investment in the United States. It would be hard to argue that the corruption scandals and the bankruptcies of 1873 took overseas investors by surprise. After all, America had undergone a full-scale financial panic in 1857. And the first American financial crisis had come some two decades earlier, when a quarter of America's states defaulted on significant quantities of their debt. After the crisis of the 1830s, British and other international lenders were wary of lending to any level of the U.S. government for a decade or so. As a look back at figure 3 will confirm, the crash of 1873 affected British overseas investment not just in the United States but elsewhere as well. Economies far removed from Erie magnate Jay Gould's assault on the gold market, or from the river of bribes that the promoters of the Union Pacific Railroad paid to congressmen to get their votes for subsidies for transcontinental railroad construction, felt the stringency as well.

Quantitative estimates of the amplitude of the U.S. business cycle back in the 1870s are of very poor reliability. But the panic of 1873 had a clear impact on financial markets. The call money rate in the key month of the crisis, September 1873, averaged more than 61 percent: anyone with money to lend that month and the courage to lend it, and who succeeded in choosing a borrower that repaid, made 5 percent over that month alone. But the effect on the real productive economy is less clear. One quantitative measure of the effects of this financial crisis comes from looking at the time pattern of railroad construction. As figure 4 shows, in 1870 and 1871 U.S. railroad construction reached its post-Civil War peak. The number 
Figure 4. United States: Growth in Railroad Construction, 1850-90

Percent change in operated track miles from previous year

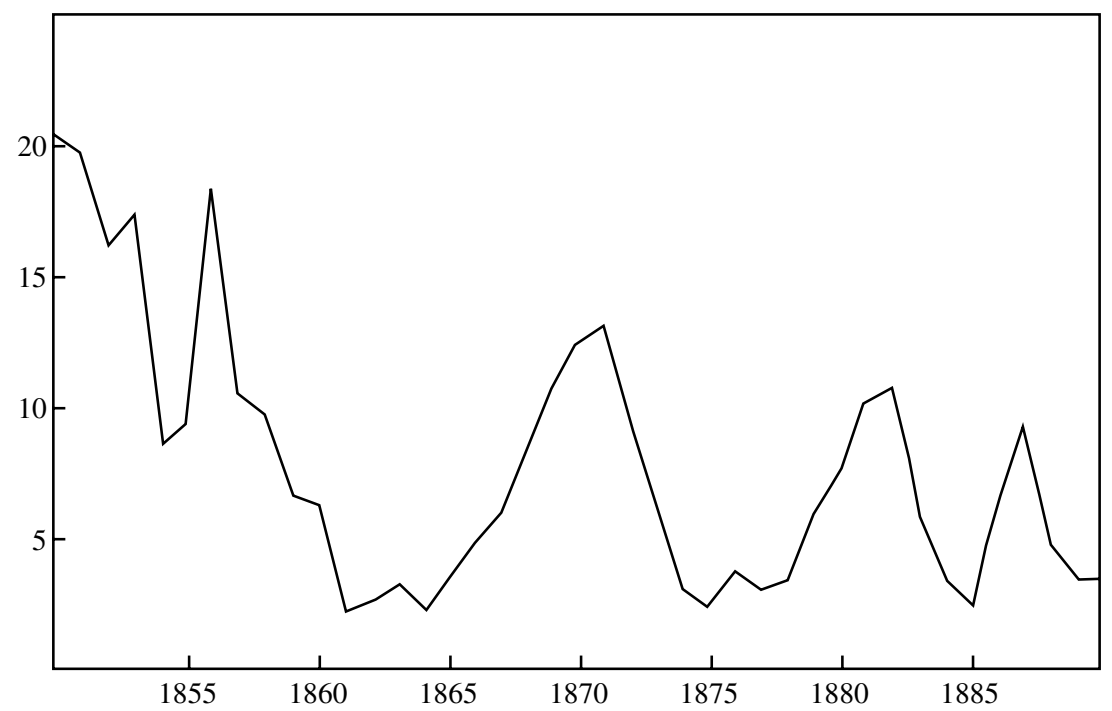

Source: Author's calculations from Historical Statistics of the United States.

of miles of operated railroad in the United States, then around 50,000, was growing at about 12 percent a year. The construction of 6,000 new miles of railroad every year employed perhaps one-tenth of America's nonfarm paid labor force and absorbed half of the potential production of America's metal industries.

Four years later, in the wake of the crisis, railroad construction had collapsed. In 1875 , operated railroad mileage grew by only 3 percent. Railroad construction then employed less than 3 percent of America's nonfarm paid labor force and required perhaps 15 percent of the potential production of America's metal industries. We know what happened next to the metal industries: they shut down, the less efficient ones permanently. We do not know what happened to the workers. It is suspected that they largely returned to farms owned by their relatives until the nonfarm economy expanded again.

However, a decade later domestic and foreign investors were back. British overseas investment grew to a new cyclical peak of 7 percent of 
British GDP by the late 1880s, and the United States received its standard proportional share. Once again the U.S. economy underwent a great railroad construction boom, with the number of miles of track in service growing at 10 percent a year. O. M. W. Sprague, reviewing the monetary and financial history of the United States for Congress after the panic of 1907, found financial crises worth writing about (each with a foreign origin or a substantial international component) in 1890, 1893, and 1907 as well as in 1873 and $1884 .{ }^{29}$ This works out to one major financial crisis every eight years for the pre-World War I United States-a pace that no single country in the current generation has matched.

The U.S. experience was not atypical. Latin America suffered through similar financial crises, driven by similar patterns of optimism and retrenchment. Carlos Marichal narrates three major international lending cycles in Latin America before 1914: the first ending with a crash in 1825, the second ending with the 1873 crisis in North America triggered by the collapse of Jay Cooke and the Northern Pacific, and the third ending in 1890 with the spectacular first bankruptcy of Barings and the default of the Argentine government. But in Latin America as well, capital flows resumed - within less than a decade after the crises of 1873 and $1890 .^{30}$

The causes of these financial crises are not straightforward. The 1873 crisis is traditionally blamed on revelations of corruption in American politics and on Jay Cooke's decision to go double-or-nothing when the Northern Pacific Railroad fell behind schedule. But why should revelations of corruption in North American politics-corruption that struck observers there as more or less business-as-usual-have led British investors to shun Latin America as well?

The 1884 crisis appears to have had its origin in Britain. The crisis of 1890 appears to have originated in Argentina (with the caveat that Barings had seen what might be coming in 1888, and it, too, had made a doubleor-nothing wager). The 1893 crisis appears to have resulted from fears in Britain that populist political pressures would force America off the gold

29. Sprague (1910).

30. Ford (1962); Marichal (1989). Australia, the third recipient of large-scale capital inflows from Britain before World War I, saw pronounced investment cycles as well. Davis and Gallman (1999) narrate how a fall in prices of Australia's exports in 1890, coupled with banks overextended as a result of a speculative land boom in the 1880s, led to widespread bank failures and a steep fall in British investment in Australia that lasted until the beginning of the twentieth century. 
standard. Finally, Sprague attributes the 1907 crisis to both financial stringency in Britain and the extreme vulnerability generated by America's inelastic currency and four previous years of rapid macroeconomic expansion. ${ }^{31}$ Whatever its origin, the 1907 crisis was deep: U.S. pig iron production fell by 60 percent between October 1907 and January 1908. It was also widespread, affecting Italy and Australia as well as the United States, despite a lack of any clear fundamental transmission mechanism.

\section{The Lessons of History}

\section{Lessons About Financial Market Reform}

The first issue of the current debate on which this century-old financial history can be brought to bear is that of the need for structural financial market reform in emerging markets hit by crisis. Those who give a high priority to institutional reform maintain that the recent financial crises arose from the belated recognition of investors in the industrial core of the degree of corruption - crony capitalism-at the periphery. To the extent that this view is correct, and to the extent that this recognition leads to a one-shot permanent change in assessments of the value of investments in emerging markets, it follows that recovery and a return of capital inflows are unlikely without substantial institutional reform that will make finance a more level playing field.

Yet the hangers-on of Suharto have added nothing to what the financiers, investors, and entrepreneurs who guided America's economic development during the Gilded Age, and the politicians holding office during the Grant, Hayes, and Cleveland administrations, already knew about crony capitalism. Financial market reform came late to the United States: even on the eve of the election of Woodrow Wilson, Thomas Lamont, a partner of J. P. Morgan, could seriously argue to progressive attorney Louis Brandeis that it was better and fairer for everybody if the Morgan partnership represented all sides in a single corporate control transaction. ${ }^{32}$ Yet foreign investment returned to the United States time after time during this era.

31. See Sprague (1910).

32. See DeLong (1991). 
Consider, as one example, the Central Pacific Railroad's part of the first transcontinental railroad, which ran from San Francisco to Ogden, Utah, where it linked with the Union Pacific in 1869. The federal government contributed \$24 million in cash (and 9 million acres of land) to the Central Pacific. The cities of northern California pitched in as well, after one of the railroad's promoters, ex-governor of California Leland Stanford, hinted that cities that did not fund the railroad might find that the railroad bypassed them. Bonds were sold in New York and London as Central Pacific founders Stanford, Colis Huntington, Charles Crocker, and Mark Hopkins advertised the profits that could be reaped from what would be for a decade or more the only rail connection to California. ${ }^{33}$

What Stanford, Huntington, Crocker, and Hopkins did not advertise was that they, as officers of the Central Pacific, had subcontracted construction work for the railroad to the Central Pacific Credit and Finance Corporation, which they owned. The shareholders of the Central Pacific wound up with a heavily indebted railroad, and the owners of the Central Pacific Credit and Finance Corporation wound up with fortunes. A substantial part of Leland Stanford's share would later serve as the core endowment for one of the best universities in California. ${ }^{34}$

It is not clear which other politicians shared in the profits of the Central Pacific. The record of the Credit Mobilier investigation into the Union Pacific suggests that a substantial amount of money flowed back to those members of Congress who had voted for railroad subsidies. Matthew Josephson claims that Colis Huntington went so far as to write that bribing politicians was his moral duty: "If you have to pay money [to a politician] to have the right thing done, it is only just and fair to do it... . If a [politician] has the power to do great evil and won't do right unless he is bribed to do it, I think ... it is a man's duty to go up and bribe [that politician]. ..." 35

The best of America's robber barons was probably E. H. Harriman, a careful executive with a talent for picking engineers to improve the operations of the Union Pacific Railroad and a willingness to invest in infrastructure now to make profits later. His friends said that Harriman was

33. Evidence suggests that the monopoly railroad did charge all that the market would bear. Freight rates appear to have been only a hair below water-and-land transport rates via the isthmus of Panama until the completion of the second transcontinental railroad. See Jue (1999).

34. Riegel (1926); Josephson (1934); Lewis (1978).

35. U.S. Congress (1873); Josephson (1934). 
honest and incorruptible. His enemies-including J. P. Morgandisagreed. Harriman also controlled the Illinois Central Railroad. Once, while chairing an annual meeting, Harriman made the unexpected ruling that the provision of the Illinois Central's bylaws that allowed for proxy votes was invalid because it was in conflict with the laws of the state of Illinois. The Morgan family's clients were primarily in London, did not want to attend meetings in America, and had given J. P. Morgan their proxies. The Morgan candidates for the board of directors were not elected. ${ }^{36}$

Leland Stanford's way of doing business surely had substantial costs. The risk that an investor in London would find out ex post that his money was in the hands of a ruthless robber baron was not a "fundamental" source of risk that should have been taken into account in calculating the optimal capital flow from nation to nation.

Some saw a market opportunity in the resulting conflict of emotions in the hearts of London investors: of fear that their agents would prove dishonest, and of greed for the high returns they might reap from financing the industrialization of the global periphery. As the Gilded Age began, J. S. Morgan sailed from New York to London, leaving his son J. P. Morgan behind in America to keep track of what was going on in Philadelphia, New York, and Hartford. The elder Morgan held himself out to British investors as an honest broker who had excellent lines of communication with the United States. He promised to steer British investors away from those railroads in the grasp of the true robber barons and toward those managed by sober, honest executives and engineers, in return for a modest finder's fee.

This broad strategy was successful. The reputation, contacts, and wealth accumulated thereby were the keys to J. P. Morgan's turn-of-the-century dominance over American railroad reorganizations and industrial finance. And later on, clients who believed that the Morgans pére and fils had guided them well in railroad finance in the 1870s, 1880s, and 1890s were willing to accept, in the 1900s, the Morgan partnership's declarations that the manufacturing and industrial enterprises it financed were worthwhile investments as well. ${ }^{37}$ The magnitude of the fortunes amassed by J. P. Morgan and his partners is an index of the size of the resource misallocations caused by crony capitalism, American style. They suggest that the Har-

36. Corey (1930).

37. Chernow (1990); Carosso (1987); DeLong (1991). 
berger triangles lost (deadweight losses incurred) as a result of American crony capitalism are likely to have been large as well.

But on the narrower issue-is financial market reform needed for recovery and for a resumption of large-scale capital inflows?-the answer is a clear no. Waves of foreign capital returned to nineteenth-century America after each panic and crash. And they returned not just to invest in firms that had the stamp of approval of sober investment banks concerned with their own long-term reputation, but to invest in other, more speculative, risky, and robber baron-ridden enterprises as well. From one perspective, this makes institutional reform in crisis-afflicted countries today less pressing, by showing that it is not necessary for recovery. Moreover, economists who make strong recommendations about optimal systems for organizing corporate control risk exceeding their knowledge. True, the American system does provide a relatively level playing field for providers and users of capital. Yet it also suffers from the problem identified by Adolf Berle and Gardiner Means: who will monitor a firm's managers when shareholders have every incentive to free-ride on others' monitoring of those managers ${ }^{38}$ As already noted, the financial systems of East Asia-information asymmetries, tilted playing fields, and all-have supported the fastest growth over an entire generation that the world economy has seen anytime, anywhere. A decade ago their systems of financial organization were seen not as examples of destructive "crony capitalism" but as adaptations of a Germano-Japanese system of large-scale bank-led finance that was efficient for late industrializers, at least until they caught up to the world's industrial leaders. ${ }^{39}$

From another perspective, however, the likely return of capital inflows makes institutional reform more important. The information asymmetries that caused so much trouble in East Asia in 1997-98 will again cause trouble when the next wave of international investment reaches its peak. If financial market reform is not necessary to attract foreign capital, governments presiding over newly industrializing economies will have little incentive to undertake it on their own. And in the long run we all may have a lot to lose from the absence of a level financial playing field.

38. Berle and Means (1932); Calomiris and Ramirez (1996).

39. Gerschenkron (1962). Both Barry Eichengreen and Jeffrey Frankel have, in conversation with the author, stressed the possibility that the Germano-Japanese system of financial organization has advantages at early stages and the Anglo-American system at later stages of development. 


\section{Lessons About Rescue Packages}

The second live issue is the role of the IMF and the rescue packages it provides. Do these packages ease crises and provide a much-needed timeout, during which necessary adjustments can take place? Are they ways to ride out irrational panics on the part of investors in the industrial core? Or are they the source of the moral hazard, the very factor keeping the market from handling crises on its own, easily, efficiently, and painlessly?

The answer to the simple form of this question-are IMF-sponsored rescue packages the cause of the current wave of financial crises?-is a clear no. Before World War I there was no IMF, yet there were international financial crises.

Although there was no IMF during the Gilded Age, there were occasional episodes of cross-national financial support. From time to time the Bank of England would lend to the Bank of France, when money flowing out of France reduced France's reserves, in the (correct) expectation that the gold flow would soon reverse itself and that the Bank of France would pay back the loan. The Bank of England also used borrowing as a standard strategy for dealing with an external drain from its own coffers.

But this pooling of reserve resources was open to hard-money western European central banks only. ${ }^{40}$ Outside the circle of the Bank of England, the Bank of France, and the Bank of Germany, large-scale support for an economy facing a balance of payments crisis was simply not available. Other countries facing crises had to meet them with their own resources, with no public bridge loans to buy time during which policy changes could take effect, and no support to outlast the pessimistic animal spirits of investors in the industrial core.

By contrast, such rescue packages are a prominent feature of the international financial landscape today. Approximately $\$ 25$ billion in additional funds was lent to the Mexican government in early 1995, albeit for shorter

40. Eichengreen $(1992,1997)$. Perhaps the Belmont-Morgan syndicate of the early 1890 s should also be counted as an international support package. This was a successful attempt to replenish the U.S. Treasury's gold reserves in the face of speculation that the Populists would attain their demand for the free coinage of silver and hence for the United States to abandon the gold standard. On the one hand, August Belmont, Jr. (a frequent partner of the Rothschilds) and the Morgans were certainly private, if very large, investment bankers. But if one believes that a central bank is anything that functions like a central bank, the Belmont-Morgan syndicate qualifies. But this is the only pre-World War I example of support for a borrower country in substantial financial trouble (see Carosso, 1987). 
time periods than seemed wise to many observers. Roughly twice as much has been and is being provided to Brazil. And the funds committed to East Asia in the past two years have been an order of magnitude larger than those provided to Mexico.

A more sophisticated formulation of the moral hazard hypothesisand a common complaint - has been that these international rescue operations have been a major contributor to the severity of recent crises, if not their sole cause. Why hesitate to lend to a banking system in trouble if one is confident that the IMF will bail out the government, the government will bail out the banking system, and the banking system will repay you, the lender, if things turn out badly? The answer to this criticism is much less clear. Again, it is difficult to prove a negative. The theoretical effect is there. So the presumption must be that there is an effect. But given all of the other factors involved, it is hard to see how it could be a large effect.

The standard counterargument to this criticism is that the IMF does usually get repaid, both principal and interest, and that the public humiliation of having to borrow from the IMF is a further deterrent. Moral hazard requires a net injection of funds. As long as there is no net injection of funds, there can be no moral hazard.

Yet this argument is not fully convincing. The domestic banks and those who lent to them do get rescued. It is domestic taxpayers in the country being rescued-who had little influence on the financial decisions that went awry-who end up repaying the IMF. Rescue packages that are repaid may not create moral hazard because they are not a net injection of funds. But rescue packages do give governments the hard currency that governments then need to create moral hazard. In the jargon of modern pop psychology, even if the IMF gets repaid in full and is not a creator of moral hazard, it is nevertheless likely to be an enabler of moral hazard. The argument that the IMF's operating procedures prevent the problem from even arising is not sufficient.

But the theoretical presumption that the existence of rescue packages has encouraged investors in emerging markets to ignore the risks of financial crisis is not, by itself, enough to settle even the theoretical issue. Any social planner attempting to calculate the desired flow of capital to emerging markets would look at the expected profits from investment- the marginal product of the capital - and discount appropriately for the risk that the investment might turn out to be unproductive. Such a social planner 
would not discount for the possibility that investors in the industrial core might have an irrational change of sentiment and seek to pull their investments out. Such a source of risk is not "fundamental"; it has no place in any social welfare calculation.

To the extent that financial crises are caused by such shifts in animal spirits on the part of investors in the industrial core, it is socially efficient for public action to offset this source of risk. It is only "fundamental" and not "noise" risk that should be priced..$^{41}$ Moreover, it is likely that international efforts to encourage the quick resolution of banking crises and to provide resources for recapitalization have contributed to earlier recovery from banking crises. ${ }^{42}$ These benefits must be set off against any potential costs from any additional moral hazard.

What does history say about international rescue packages? The late nineteenth century shows clearly that an absence of such packages is not a sufficient condition for eliminating international financial crises. Thus extreme claims-no rescue packages, no financial crises like those seen in Mexico or in East Asia-are unsupported. Large-scale international capital flows appear to generate major international financial crises on their own, without the IMF's help.

Those who believe that the availability of rescue programs has increased the severity of international financial crises can point to calculations by Bordo, Eichengreen, and Douglas Irwin using data from the Bordo and Schwartz database. These calculations show that financial crises before 1914 were somewhat less severe on average than recent ones have been. There appears to be an average 3-percentage-point decline in GDP growth relative to trend during the crisis year in crises since 1972, compared with an average 2-percentage-point decline relative to trend in the crisis year in crises before $1914 .^{43}$

Those who believe otherwise can point, as Bordo and Eichengreen do, to the fact that including the financial crises associated with the outbreak of World War I in the pre-Depression sample makes the average pre-

41. See DeLong and others (1989).

42. Stanley Fischer has observed, in conversation, that the contrast between the Mexican financial crises of 1982 and 1995 seems instructive. Growth resumed just one year after the peak of the second crisis, but not until five years after the peak of the first crisis. Mexico received no large-scale IMF or other public support in the first crisis. But in the second crisis Mexico got substantial support from the IMF and from the United States.

43. Bordo, Eichengreen, and Kim (1998). 
Depression financial crisis more severe. One can also note that the most severe crises of the pre-1914 period-Argentina in 1890 and the United States in 1893-had more severe real consequences than any of the recent series of crises. Bordo and Eichengreen calculate that Argentine economic growth in the crisis year was 17 percentage points below trend and that U.S. growth was 9 percentage points below its five-year trend; these magnitudes far exceed Korea's 7-percentage-point decline in GDP growth relative to trend during the recent episode. The difference is especially striking when one considers that East Asian trend growth rates of GDP per capita in the precrisis 1990 s were three times those in the United States or Argentina in the precrisis 1880 s. $^{44}$

The fact that it is hard to find clear differences in the magnitude of the real effects between the recent international financial crises and those before 1914 is both heartening and disheartening to supporters of international financial rescues. What is heartening is that history gives no strong reason to think that the Mexican or the Asian crisis was outside the bounds of what the "normal" workings of a market economy with large international capital flows might generate. If the Mexican and Asian crises had no counterparts as large or larger in relative terms back before World War I, it would be good reason to think that the current international monetary system — of which IMF-led rescue packages are a significant partis a less effective social mechanism for handling crises than the pre-1914 classical gold standard was. On the other hand, what is disheartening is that this historical comparison supplies no evidence that the current international monetary system is superior to the classical gold standard at handling international financial crises.

\section{Lessons About Exchange Rate Regimes}

The third important issue is the appropriate exchange rate policy to avoid or handle a crisis. Is it better to regard the exchange rate as a price that one can freely move about to switch and guide expenditures? Or is it better to regard it as a promise: to incur substantial costs in order to keep the exchange rate pegged, and hope that keeping promises made in the past will create the expectation that promises will be kept in the future? 
The most striking difference between the institutions that prevailed during the first era of globalization and those that prevail today is the difference between their monetary regimes. The half-century before World War I was the era of the classical gold standard. Country after country joined Britain in pegging its currency to gold. The expectation was that currencies, or at least the currencies of well-run countries, would have stable exchange rates into the indefinite future. This became a natural background assumption that governed the expectations of nearly all international investors.

By contrast, today's international monetary system is one of nearly clean floating among the four major world currencies-the dollar, the euro, the yen, and the pound-and a variety of dirty floats, pegs, and semipegs on the part of most other countries. The live question today as far as the choice of exchange rate policy is concerned is whether to float, to peg, or to dollarize (or perhaps, in the near future, to yenize or euroize). In recent years the middle range of exchange rate policy options has hollowed out. Many former advocates of weak pegs or dirty floating now think that such systems combine the disadvantages of a float and of dollarization. And so the extremes have gained ground.

Before World War I, adherence to the gold standard meant that the policy goal of the government was to maintain the gold parity of the currency and to restore the currency to that parity should it fall below par as a result of a crisis. Thus commitment to the gold standard ensured that, once the resolution of the crisis was in sight, capital inflows would become stabilizing rather than destabilizing. Depreciation would be viewed not as a sign of the likely collapse of the value of the currency, but as an opportunity to make capital gains by buying up the currency. ${ }^{45}$

During the U.S. suspension of payments in 1907, for example, cash dollars (and gold and foreign exchange) went to a premium of 2 percentage points over dollar bank deposits (and other internal domestic means of liquidity). Such a depreciation in the value of the banking-system dollar seems very small in our eyes: we are used to seeing financial crises bring depreciations of 20 or even 50 percent. But because the commitment to the gold standard was believed, this small (and illegal) emergency depreciation was sufficient to bring the flow of money out of the U.S. banking 
system to a halt. The 2 percent capital gain expected when the crisis would be over and the U.S. banking-system dollar would return to its normal parity was enough to balance fears of financial institution bankruptcy and the need for extra liquidity. ${ }^{46}$

Thus, for Australia, Canada, and New Zealand, and for the United States after the effective end of the Populist movement, the fact that the exchange rate under the classical gold standard was viewed as a firm promise was a great help in resolving financial crises. For other countries, and for the United States in the early 1890s (when the Populist movement cast doubt on its long-run commitment to the gold standard), the fact that the government's commitment to the gold standard was not seen as an unbreakable promise was a potential source of disorder.

Milton Friedman and Anna Schwartz, for example, concluded in their Monetary History of the United States that in the early 1890s the United States had the worst of both worlds. The fact that the political establishment saw the gold standard as the only appropriate economic policy meant that the United States stuck to the gold standard. But the fact that foreigners saw the Populist movement as likely to gain power and force a depreciation meant that sticking to the gold standard required very high real interest rates, which depressed investment and production throughout the first half of the 1890s. ${ }^{47}$ As figure 5 shows, except for the Great Depression, the depression of the 1890s was by far the worst, as measured by the level of unemployment, that the United States has experienced since 1890 , the earliest date for which aggregate annual estimates are available..$^{48}$

The lesson from history seems to be that a strong, credible, and credited commitment to a fixed exchange rate parity does indeed have substantial benefits. The problem is, How does a country create the necessary belief in its commitment? The European crisis of 1992 showed that not even Britain

46. Sprague (1910).

47. Friedman and Schwartz (1963).

48. Romer (1986). Note that the numbers plotted in figure 5 include the corrections suggested by Romer, which significantly reduce the estimated unemployment rate in the 1890s below that given in the bicentennial edition of Historical Statistics of the United States. Claudia Goldin has pointed out that the United States in 1890 was still in large part a rural economy, that there is a powerful argument that rural unemployment and underemployment are disguised and never make it into historical statistics, and thus that the appropriate denominator is not the total but the nonfarm labor force. In that case the $1890 \mathrm{~s}$ look half again as bad relative to, say, 1982. 
Figure 5. United States: Unemployment Rate, 1890-1998

Percent

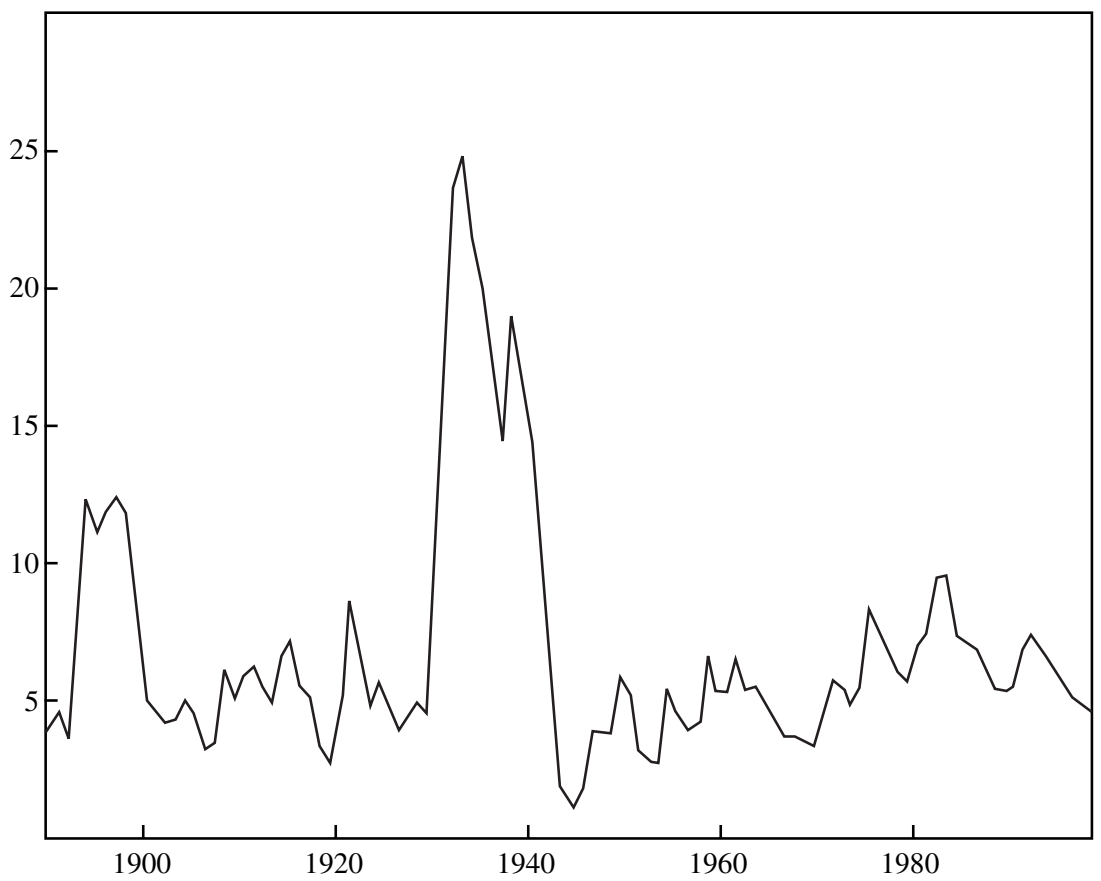

Source: Author's calculations from Historical Statistics of the United States and Romer (1986).

under a conservative government had that much credit with the community of foreign exchange traders.

Eichengreen has argued that the disastrous interwar experience demonstrates that the kind of commitment to a fixed parity needed for the classical gold standard to function well is not possible for a stand-alone currency in the modern age. In this age of mass politics it is generally recognized that government policies can have powerful short-run effects on production and employment, and suffrage is extended well beyond those who have a financial interest in hard money. These two factors make it noncredible for any government to claim that it is committed to a fixed parity regardless of the macroeconomic consequences. And when the government's commitment is not believed, a fixed parity does not seem to work 
well at all. During the Depression, the longer governments maintained their parities, and the more strongly they tried to commit themselves to the gold standard, the worse their economies performed. ${ }^{49}$

These conclusions are pessimistic ones. But it is difficult to find an alternative explanation for the failure of orthodox "classical" policies to bring recovery during the Great Depression, given their apparent success at producing rapid recovery in the years before World War I. ${ }^{50}$ Something must have changed about the environment in which economic policy was made.

\section{Conclusion}

The freedom of movement of capital has grown since the 1960s and has brought substantial benefits. It is difficult to see, for example, how the United States could have managed the decade of the Reagan budget deficits without strong and visible damage to capital accumulation and economic growth had it lacked the ability to borrow abroad on a large scale. The promise that growth-promoting macroeconomic policies will attract capital from abroad gives developing-country governments an additional incentive to take the long, growth-oriented view. The opportunity for a newly industrializing economy to borrow from the industrial core to finance its development is perhaps the consequence of international capital mobility that offers the greatest social benefit, if it can be attained. It would mean that such countries can cut perhaps a decade off the time they need to achieve industrial-country standards of living. But the free flow of financial capital is also giving us a major international financial crisis every four years. And there is no reason to think that the East Asian crisis of 1997-98 will be the last.

The great macroeconomists of the Depression era-John Maynard Keynes, Harry Dexter White, and their peers-would say that we now need to heed the lesson that they themselves learned in the Great Depression. Capital controls and other devices are needed to keep international flows of investment small, manageable, and firmly corralled. Financial

49. Eichengreen and Sachs (1985); Campa (1990); Eichengreen (1997); Eichengreen and Temin (1997).

50. Eichengreen (1992). 
markets, in the view of Keynes and White, are too subject to episodes of herd behavior for large-scale international capital flows to be tolerated.

Over the past decade, however, we economists have bemoaned the fact that capital controls keep people in industrial countries with money to lend away from people in developing countries who could make good use of that money. We have argued that capital controls are difficult to maintain. We have noted that capital controls appear to have been a source of bad government and corruption on a large scale. The balance of opinion over the past decade has been that stringent capital controls sacrifice too much in the way of economic growth-but this balance may be shifting.

A look back at history shows no easy way of controlling the macroeconomic instability that large-scale capital flows create. History does leave clues that a strong, credible, and credited commitment to unalterable exchange rate parities would do some good, but we do not know how to create such a commitment in the age of mass politics by any means short of dollarization. And dollarization appears much more appealing today, after two decades in which U.S. macroeconomic policymakers have been both skillful and lucky, than it would have appeared two decades ago or may appear two decades hence. There is a sense in which the differences between the Bretton Woods system in its heyday and mass dollarization are subtle ones.

History does not suggest that we could eliminate crises if only we eliminated the rescue packages that have been devised to manage crises. It does not suggest that the creation of international agencies to fund rescue packages has created the problems with which the IMF now deals. On the other hand, neither does history suggest that the international economy today is more stable than it was in the last great era of globalization. Economists who believe that IMF-sponsored support packages have done much good now have the task of pointing to other factors that have changed and made the world economy more unstable, that is, more prone to financial crisis, than it was back before 1914 .

Finally, history does not suggest that the fight for a more level playing field between borrowers and lenders-as worthy a goal as that is-will have much effect one way or the other on the incidence of crises like those we have seen in the 1990s. A more level financial playing field is likely to make the benefits from international capital flows greater. But there is no reason to see it as a necessary prerequisite for recovery, or as a panacea that will protect against future crises. 


\section{Comments and Discussion}

Richard N. Cooper: Henry Ford is reputed to have said that "history is bunk." I presume he meant at least that one cannot learn from history anything useful for guidance in the present or the future, and perhaps even that history is positively misleading with respect to the present and the future. Bradford DeLong's paper is a concrete counterexample to the Ford proposition.

One of the important uses of history is to debunk currently fashionable social scientific generalizations, such as, in the case at hand, theories about what will and will not produce financial crises, and what are the consequences of those crises. In short, historical material can help us to sort among competing durable hypotheses about human behavior.

DeLong nicely uses the late nineteenth-century period of globalization, to use the current buzzword, to cast serious doubt on three currently fashionable generalizations coming out of the financial crises of the past four years. The first is that crony capitalism has to be severely curtailed before capital flows will resume to countries where crony capitalism is endemic. U.S. history suggests, as DeLong colorfully points out, that that claim is simply false. Why it is false-whether because new, inexperienced investors replace the ones who have been burned, or because memories are short, or because crony capitalism actually facilitates foreign investment-is a subject for serious inquiry, but the proposition that capital will not return relatively quickly does not stand historical scrutiny.

The second, which has been invoked by people of high political prestige and authority, is that recent financial crises have been caused by the prospect that the International Monetary Fund will "bail out" countries and hence foreign creditors that run into difficulty. Without this prospect, it has 
been argued, much less international lending would have taken place, and that lending would have been solidly based.

DeLong shows that, even in an era in which there existed neither an IMF nor any functional substitute for it, a large amount of foreign investment took place (relative to the other economic magnitudes of the time). $\mathrm{He}$ also shows that, sure enough, financial crises occurred, placing the foreign lenders at risk. Although one cannot infer from this information that the presence of the IMF played no role in recent international lending, one can state that a quasi lender of last resort is not a necessary condition for much foreign lending that, ex post, turns out to have been ill advised.

The third generalization is that fixed exchange rates ensure financial crises and that floating the exchange rate is a way to avoid such crises in the future. As DeLong points out, late-nineteenth-century history offers less guidance on this question, because the expectational environment was completely different under the gold standard in the 1890s than it is under fiat money in the 1990s. Nonetheless, simple generalizations about fixed or floating exchange rates are unlikely to be universally correct, and even here history suggests a degree of caution about contemporary generalizations.

Let me say a word about the recent crises. In my view, the IMF played essentially no role in creating moral hazard in all but one of the financial crises during the past four years. The exception is Russia, where the prospect of an international bailout probably did lead foreign investors to buy more Russian government securities than they would have otherwise. But here it should be said that the IMF was simply the point man for Germany and the United States, with support from other G-7 countries. These industrial powers did not want to see a collapse of Russian economic reforms, of Russian democracy, or of effective central control over Russia's strategic nuclear weapons.

Moral hazard was abundant in these several crises, but it was overwhelmingly associated with crony capitalism, where many local borrowers could and did assume that their government would bail them out if they got into financial difficulty. That view would have prevailed with or without the IMF.

DeLong emphasizes the importance, in long-term and long-distance lending, of information asymmetries, and of the role in U.S. history of J.P. Morgan, who established himself as an honest broker between lenders and borrowers, thus effectively reducing those asymmetries. I accept the importance of such asymmetries in many circumstances, but I doubt they 
deserve primacy of place in all financial crises. Surely there were few if any information asymmetries in Europe's financial crises of 1992. The situation was quite transparent. All relevant players could see the range of possible outcomes, they made different guesses on what would happen, and some of them thereby forced events.

I would instead emphasize the intrinsic fragility of all financial markets. That fragility arises from the simple fact that most lenders want to get their money back whenever they need it, whereas most borrowers want to keep the money for as long as they need it. The trick of all modern and wellfunctioning financial markets is to appear to satisfy these conflicting desires of both lenders and borrowers. Loans appear liquid to the lenders, durable to the borrowers. Maturity transformation is a critical element in financial intermediation. But it involves an illusion. To work, it relies on the law of large numbers, or more accurately, on the broad independence of the liquidity needs of different lenders, so that the intermediaries can satisfy both the ultimate lenders and the ultimate borrowers.

But from time to time the law of large numbers breaks down, sometimes dramatically, and many lenders want their money at the same time. This can happen either because they make that decision independently of each other-a low-probability random event—or more often because some new information (or possibly misinformation) triggers a common reaction.

Recently a well-regarded life insurance company, General American, narrowly avoided financial collapse. It was engaged in relatively modest maturity transformation, but it either forgot or chose to ignore the fact that its short-term borrowing, nominally with maturities of 90 or 180 days, had 7-day call provisions. The bond rating agency Moody's downgraded General American's debt from AA2 to AA3 and directly informed the lenders of the rating change. Many lenders then invoked the 7-day provision, and General American nearly went under. It managed to find a buyer, so the policyholders were protected. But its maturity transformation was dramatically undone by a triggering event, in this case by an entirely unaccountable private party, the rating agency.

Maturity transformation with its attendant risks is a general characteristic of all modern financial markets. We have created a complex institutional structure to minimize the real and financial damage that can be caused by financial market failure. We have rules and regulations to inhibit important financial institutions from taking undue risks and to ensure that they have enough capital to cover normal risks. We create lenders of last 
resort to liquify otherwise illiquid bank assets. This elaborate structure may offend free marketeers, but in my view some such structure is necessary for well-functioning markets, and without it some financial markets would not exist.

Countries such as Thailand and Korea, where the real economy registered outstanding performance for several decades, failed to evolve the financial superstructure in tandem, and the financial crises of 1997 reflected the mismatch between the requirements of their real economies and the evolution of their financial systems. As DeLong's paper reminds us, Americans have no grounds for being smug on this score: the United States experienced financial crises on average every eight years during a corresponding period of its development. And it took the catastrophe of the Great Depression to get us to put in place the complex regulatory system that has served the U.S. economy well during the past sixty years-although even that did not protect us from the savings and loan crisis of the 1980s.

I have a few quibbles with DeLong's paper. First, he suggests, in discussing the European financial crises of 1992, that it was only the belief that macroeconomic policies would prove unsustainable that made them unsustainable and inappropriate. That was certainly not the case for Italy, whose exchange rate against the deutsche mark had been unchanged for over five years despite considerably higher inflation rates in Italy than in Germany. It was arguably also not the case for Great Britain and Sweden. Britain had gone into the European Exchange Rate Mechanism in 1990 with what was widely believed at the time to be an overvalued pound sterling. Sweden faced a banking crisis arising from excessive lending in the 1980 s, which at least suggested that the traditional Swedish strategy of cushioning imported recessions with stimulative monetary and fiscal policy was no longer feasible.

Second, DeLong suggests that the East Asian countries were pursuing appropriate macroeconomic policies. It is true that by comparison with most Latin American countries in the 1980s their policies were exemplary. But Thailand's difficulty arose largely from inappropriate macroeconomic policy in the circumstances of late 1996 and early 1997. As in Mexico in 1994, the central bank continued to finance from reserves a large current account deficit that was no longer covered by sufficient net capital inflows, and it sterilized this intervention. (It also neglected to report publicly the rapid decline in usable foreign exchange reserves, in a clear case of asymmetric information.) 
Finally, in his concluding remarks DeLong says that the balance of professional opinion is that stringent capital controls sacrifice too much in the way of economic growth (and have other compelling disadvantages) to be useful. The operative word here, in my view, is "stringent" rather than "capital controls." There is a wide gradation of possible restrictions on international capital movements. As I argued in the last issue of the Brookings Papers, ${ }^{1}$ at least some forms of restriction on capital movements in some circumstances are likely to be growth enhancing rather than growth reducing.

Benjamin M. Friedman: One would have to have been living in a closet not to be aware that the events of the 1990s in world financial markets have called sharply into question key elements of what used to be standard dogma among many economists and market participants. Is there anyone left who still believes that currency fluctuations mostly reflect the changing outlook for differences in countries' rates of price inflation? Or that currency market speculation is mostly if not always stabilizing? As Jason Furman and Joseph Stiglitz showed in an article in the Brookings Papers last year, ${ }^{1}$ comparing the experiences of different Asian and Latin American countries in the rolling crisis of 1997-98 even provides evidence against the comforting view that countries with higher indebtedness are more likely to get into financial trouble. The evidence they assembled also contradicts the view that international investors place value on, and hence reward, financial "transparency." Finally, does anybody not directly employed by a bond fund still believe that the forces that William Gross at Pacific Investment Management calls the "bond market vigilantes," and that Thomas Friedman of the New York Times calls "the electronic herd," do a good job of policing countries' macroeconomic policies? Alas, the bond market vigilantes turn out to be simply investors who have somehow discovered the ultimate truth that bad news is bad because it's bad and good news is worse because it's inflationary.

The demolition of so many propositions that only recently commanded widespread support (at least in some quarters) has created a new debate. The chief issue is what either individual countries or the world financial community acting in concert should do to reduce the likelihood of future

1. Cooper (1999).

1. Furman and Stiglitz (1998). 
crises and to minimize the consequences of those that do occur. The task Bradford DeLong undertakes in this paper is to see what lessons we can draw to inform that debate from economic history, especially U.S. history from the era when the United States relied heavily on borrowing from abroad to finance the nation's early industrialization. As one would expect from his earlier work, DeLong tells this story with verve and flair, imparting along the way something of the color and even the drama of an earlier America whose shortcomings we now willingly submerge in the romance of nostalgia. He even reminds us that, in America, universities are the ultimate money launderers. (As the sons of the Puritans who for centuries managed my own institution always seemed to maintain, no matter how sordidly you earned it, once you have given it to Harvard and Harvard has spent it, in the eyes of God and man it is cleansed.)

What, then, can this history teach us about the important questions that perplex both public policymakers and private market participants in the wake of the events of the 1990s? DeLong draws three conclusions from the history he reviews. The most significant of these is that fairly soon after a financial crisis has cleared up-even if the failure of borrowing countries' institutional arrangements and the malfeasance of specific borrowers have been a large part of the story - capital once again begins to flow to those same countries and often to those very borrowers. Hence reforms of the kind demanded by the International Monetary Fund from key Asian countries in the most recent crisis have historically not been a necessary condition for the resumption of lending.

This conclusion is interesting not only because it speaks to a question of genuine practical importance in many borrowing countries today (for example, in Indonesia, Korea, and Thailand) but also because it squarely contradicts familiar views on this subject. Even if the bond market vigilantes did know how to distinguish good economic policies from bad, they would not insist on good ones anyway — or if they did, they would not be able to make their insistence stick. Similarly, it is wrong, historically, to think of the electronic herd of institutional lenders as powerfully imposing its will on important borrowers. On DeLong's evidence, it might be just as plausible to see these lenders as mere cattle, whom the borrowers, sitting tall in the saddle, herd from one country to another to be milked and slaughtered.

DeLong's second conclusion from the historical evidence is straightforward. Frequent breakdowns in lending markets, not unlike what we 
have seen in the last half-decade, also occurred in an earlier era when there was neither an IMF nor any other visible international safety net. Hence it is wrong to point to moral hazard created by the IMF, or by parallel arrangements, as a necessary condition for the markets to experience such problems. Correspondingly, it is wrong to think of reforming the IMF, or even of abolishing the institution as some have recently suggested, as sufficient to prevent such crises from recurring.

This finding is no doubt true, but weak (as DeLong also makes clear). The relevant question is not whether moral hazard due to the IMF's safety net is a necessary ingredient in financial crises but, more broadly, what role moral hazard plays in accounting for the existence and severity of the crises we have seen. The historical evidence DeLong assembles in this area of inquiry does little more than enable us to dismiss certain extremist views out of hand. But in an era when extremists on all sides increasingly dominate the discussion, this, too, can be a useful service.

DeLong's third conclusion, on the role of currency regimes, is also no doubt true but of limited import. It is hard to dispute the claim that a system in which countries credibly commit to maintain fixed values of their currencies against some well-established benchmark carries advantages from the way market participants' expectations affect their speculative behavior. The character of those expectations, and hence the advantageous consequences of the speculation to which they give rise, are simply assumed once the word "credibly" is included. Nor is this idea new. The debate over the classical gold standard has traditionally pitted just those advantages against equally clear drawbacks. Most economists have concluded that the drawbacks dominate. In any case, as DeLong makes clear, nobody thinks that the countries at the heart of the recent wave of currency crises could make such a credible commitment within the foreseeable future.

There is an important nexus of interrelated issues that I believe should now stand at the center of economists' agenda for research, historical and other, on these matters. DeLong usefully points to questions about the moral hazard created by, for example, the IMF's safety net. To repeat, the real question here is not what is a necessary or sufficient condition for what, but rather how influential—quantitatively—such moral hazard is in accounting for what seems to be going wrong. To put the question more bluntly, and in a way that I think appropriately redirects attention in this area away from its nearly exclusive focus on the borrowers, why have international lenders been so reckless? For example, what were American 
and Japanese bankers thinking when they lent, in dollars or yen, to the Indonesian and Korean banks that were openly relending the proceeds in rupiah and won without hedging the resulting currency exposure? That they were relying on those countries' governments to rescue their banks, and in turn on the IMF to rescue the governments, is one possible answer. But there are other possible answers, and the subject deserves a serious and systematic examination.

It also helps, I think, to remind ourselves that many of these same lenders sometimes act just as recklessly in contexts in which the IMF is in no way involved. For example, what were many of these same bankers thinking when they lent in sizable amounts to Long Term Capital Management, the widely touted hedge fund that collapsed so dramatically in the fall of 1998, without receiving the right to know how the borrower was using the proceeds, much less getting to audit or even inspect the firm's books? Here too, moral hazard created by central authority may, or may not, have been an important part of the story. In the United States, in principle, this particular kind of moral hazard should apply only to those institutions deemed "too big to fail." But in practice the too-big-to-fail standard often seems highly elastic.

A quite different view, which likewise applies in both domestic and international contexts, attributes lenders' systematic recklessness to the competitive pressures bearing on financial intermediaries (banks in particular) that look to speculative markets to provide the capital that constitutes the raw material with which they conduct their business. U.S. banks long ago lost the core commercial lending business that enabled them to earn a rate of return that shareholders would see as competitive while assuming only reasonable risk. Since then most have been driven to find special market niches, to seek sources of income outside of standard banking activities, or - in all too many cases - to take on excessive risk. Is this story a good one for other countries, too? Given that it is in no way inconsistent with a role for moral hazard, what relative importance attaches to each?

Yet another potentially useful way to address some of the questions at issue in DeLong's paper would be to construct a historical counterfactual-for example, in the mode of Robert Fogel's study of nineteenthcentury American railroads-for specific episodes in recent or not-so-recent experience. ${ }^{2}$ For example, how much more (or less) would

2. Fogel (1968). 
the average citizen of Mexico have suffered economically if that country's government had simply defaulted on its foreign currency debt? Answering such a question requires making strong assumptions, to be sure. But as Fogel and others have shown in other areas of historical inquiry, it is possible to make the needed assumptions in a sufficiently sensible way that readers can draw useful lessons from the subsequent analysis.

One can think of other approaches to posing the same set of questions. One is to ask what is gained, and by whom-and what is lost, and by whom-from maintaining the fiction that nobody defaults on debt owed to the IMF, or to other official lenders for whom default is too embarrassing to acknowledge. In effect, borrowers can and do default de facto, but they are not allowed to do so de jure. Why?

Here again, the important issues are hardly limited to the international arena. In an international context, however, special considerations apply that make matters more complex. Perhaps the easiest way to see how these special factors come to bear is to recall, by way of analogy, what happens when the United States declares that it will not give aid to countries that support terrorism, or fail to combat drug trafficking, or do not comply with other important priorities of American foreign policy. Too often, the result is not that other countries change their behavior. Instead, the facts notwithstanding, the U.S. government goes ahead and certifies that such and such a country is no longer sponsoring terrorism, or is waging the good fight against the drug trade, when it is clear to everyone that this is not so. The explanation, of course, is that reasons of state demand that aid to these countries continue, and these reasons prevail.

The most recent potential example arose during the week this Brookings Papers conference was held. The Secretary of the Treasury publicly stated that the United States would support continued IMF lending to Russia only if investigation shows recent allegations of embezzlement and money laundering by Russian government officials to be false. It is not hard to predict that whatever investigation ensues will, in due course, find these allegations unfounded. (It is even possible to imagine a situation in which some of the wrongdoers might demand yet additional payoffs in exchange for not publicly acknowledging their own illicit activities.) Once a government, or any other institution, commits itself to any given fiction, it acquires an interest in seeing that fiction maintained. The relevance of all this to the set of issues raised by DeLong's paper is that today the absence 
of default on certain forms of international lending, and the infrequency of default on other forms, constitutes just such a fiction. It would be useful to know of what value that fiction is, and to whom-and, importantly, at what cost it comes.

Economic history is not the only way to answer questions like these, but I think DeLong is right to believe that the experience of longer ago than just the last few crises may have something to tell us.

General discussion: Christopher Carroll noted that advances in the evolution of financial institutions, accounting standards, and laws to prevent abuses and increase transparency have often come in response to crises. $\mathrm{He}$ believed the paper could have more fully analyzed how past crises shaped the attitudes and policies that followed them, and from that analysis could have drawn lessons for today's developing countries. In the same vein, Christopher Sims suggested taking a closer look at how the United States moved from a period of relative financial instability in the nineteenth century, through institutional reform, to the relative financial stability of the post-World War II period. A particularly interesting episode took place in the 1830s, when some American states defaulted on significant quantities of debt. In the wake of that crisis, foreign investors remained wary of lending to American governments until after the Civil War. Meanwhile states undertook reform to various degrees, with some essentially repudiating their debt and others paying its full present value. How quickly they could return to the market seemed to depend on the amount of reform effort they undertook. Sims reasoned that examining such past episodes should help in the design of reforms today, when each crisis country cares whether it can return to the capital markets in three years or fifteen years.

Robert Hall did not accept the paper's implicit message that crisis is an intrinsic feature of economies. He reasoned that short-term debt exposure lies behind crises and noted that, as a consequence, in the United States only the financial sector is vulnerable. The nonfinancial sector is overwhelmingly financed with crisis-free equity. Regrettably, however, the financial sector is more heavily leveraged with short-term debt than ever. Hall noted that if Thai companies had been financed with equity, that country would not suffered its recent crisis. At worst, there would have been a sharp decline in the value of the equity, although even that would not have been severe, because the endogenous crisis-producing mechanism that develops with short-term debt would have been avoided. Hall concluded 
that the major thrust of U.S. policy for developing economies should be, first, to induce them to get rid of short-term debt, and replace it with American-style equity markets. Carroll added that it might be necessary to export the entire institutional and legal framework associated with equity holding in the United States. Without such a framework, it may not be a good idea to buy equity in, say, an Indonesian company, given that the current corporate governance regime there provides no reason to believe that managers will act in the shareholders' interest.

David Laibson thought the paper provided a series of anecdotes about extreme and spectacular failures, but little insight into how typical foreigners fared when they invested in the United States in the nineteenth century. It would be interesting to know whether such investors should be modeled as myopic agents making suboptimal decisions, or as rational agents making sensible choices in an environment with extreme information asymmetries and many institutional deficiencies.

Alan Blinder cautioned against viewing all financial crises as alike; close attention should be paid to the details. He suggested that if Mexico and East Asia had had floating exchange rates and much less foreign currency-denominated debt, the recent crises would have been much less intense or would not have occurred at all. One of the lessons of the recent crises was certainly that rapid financial liberalization without the appropriate regulatory apparatus in place is dangerous. Blinder added that moral hazard is a continuous rather than a zero-one variable. It became a serious concern after the holders of Mexican tesobonos were fully bailed out, and it is plausible that investors were more willing to lend in East Asia after the Mexican experience. Richard Cooper disagreed, saying the importance of the Mexican bailout was often overestimated. He found it difficult to believe that paying off lenders to the Mexican government, with Mexico having just entered the North American Free Trade Agreement, would have encouraged excessive lending to private companies in Asia. Cooper also joined Carroll and Hall in their support for greater reliance on equity and the American institutional framework, and pointed out that since its crisis Korea has been converting corporate debt into equity. 


\section{References}

Bagehot, Walter. 1873. Lombard Street: A Description of the Money Market. New York: C. Scribner, Armstrong, \& Co.

Bairoch, Paul. 1993. Economics and World History: Myths and Paradoxes. University of Chicago Press.

Bairoch, Paul, and Richard Kozul-Wright. 1998. "Globalization Myths: Some Historical Reflections on Integration, Industrialization, and Growth in the World Economy." In Transnational Corporations and the Global Economy, edited by Richard Kozul-Wright and Robert Rowthorn. New York: St. Martin's Press.

Berle, Adolf, and Gardiner Means. 1932. The Modern Corporation and Private Property. New York: Macmillan.

Bordo, Michael, and Barry Eichengreen. 1999. "Is Our Current International Economic Environment Unusually Crisis Prone?" Paper prepared for the Reserve Bank of Australia Conference on Private Capital, Sydney, August 9-10.

Bordo, Michael, Barry Eichengreen, and Douglas A. Irwin. 1999. "Is Globalization Today Really Different Than Globalization a Hundred Years Ago?” Brookings Trade Forum 1999.

Bordo, Michael, Barry Eichengreen, and Jongwoo Kim. 1998. "Was There Really an Earlier Period of Financial Integration Comparable to Today?" Working Paper 6738. Cambridge, Mass.: National Bureau of Economic Research (September).

Bordo, Michael, and Finn Kydland. 1996. "The Gold Standard as a Commitment Mechanism." In Modern Perspectives on the Gold Standard, edited by Tamim Bayoumi, Barry Eichengreen, and Mark P. Taylor. Cambridge University Press.

Bordo, Michael, and Anna Schwartz. 1996. "The Operation of the Specie Standard-Evidence for Core and Peripheral Countries, 1880-1990.” In Currency Convertibility: The Gold Standard and Beyond, edited by Jorge Braga de Macedo, Barry Eichengreen, and Jaime Reis. London: Routledge.

Calomiris, Charles, and Carlos Ramirez. 1996. "Financing the American Corporation: The Changing Menu of Financial Relationships." Working Paper Series on Historical Factors in Long Run Growth 79. Cambridge, Mass.: National Bureau of Economic Research (February).

Campa, Jose. 1990. "Exchange Rates and Economic Recovery in the 1930s: An Extension to Latin America.” Journal of Economic History 50(3): 677-82.

Carosso, Vincent P. 1987. The Morgans: Private International Bankers, 18541913. Harvard University Press.

Chernow, Ron. 1990. The House of Morgan: An American Banking Dynasty and the Rise of Modern Finance. Atlantic Monthly Press.

Cooper, Richard N. 1999. "Should Capital Controls Be Banished?" BPEA 1:1999, 89-125.

Corey, Lewis. 1930. The House of Morgan. New York: Howard Watt. 
Davis, Lance, and Robert Gallman. Forthcoming. Evolving Financial Markets and Foreign Capital Flows: Britain, the Americas, and Australia. Cambridge University Press.

DeLong, J. Bradford. 1991. “Did J. P. Morgan's Men Add Value? An Economist's Perspective on Financial Capitalism." In Inside the Business Enterprise: Historical Perspectives on the Use of Information, edited by Peter Temin. University of Chicago Press for the National Bureau of Economic Research.

DeLong, J. Bradford, Christopher DeLong, and Sherman Robinson. 1996. "The Case for Mexico's Rescue: The Peso Package Looks Even Better Now.” Foreign Affairs 75(3): 8-14.

DeLong, J. Bradford, and Richard Grossman. 1993. “'Excess Volatility' on the London Stock Market, 1870-1990.” Unpublished paper.

DeLong, J. Bradford, and others. 1989. "The Size and Incidence of the Losses from Noise Trading." Journal of Finance 44(3): 681-96.

Edelstein, Michael. 1994. "Foreign Investment and Accumulation, 1860-1914." In The Economic History of Britain Since 1700, 2nd ed., vol. 2, edited by Roderick Floud and Donald McCloskey. Cambridge University Press.

Eichengreen, Barry. 1992. Golden Fetters: The Gold Standard and the Great Depression, 1919-1939. Oxford University Press.

- 1997. Globalizing Capital: A History of the International Monetary System. Princeton University Press.

- 1999. Toward a New International Financial Architecture: A Practical Post-Asia Agenda. Washington: Institute for International Economics.

Eichengreen, Barry, and Jeffrey Sachs. 1985. "Exchange Rates and Economic Recovery in the 1930s." Journal of Economic History 45(4): 925-46.

Eichengreen, Barry, and Peter Temin. 1997. "The Gold Standard and the Great Depression." Working Paper 6060. Cambridge, Mass.: National Bureau of Economic Research (June).

Eichengreen, Barry, and Charles Wyplosz. 1993. "The Unstable EMS.” BPEA, 1:1993, 51-143.

Feldstein, Martin. 1998. "Refocusing the IMF." Foreign Affairs 77(2): 20-33.

Feldstein, Martin, and Charles Horioka. 1980. "Domestic Saving and International Capital Flows.” Economic Journal 90 (June): 314-29.

Fogel, Robert. 1968. Railroads and American Economic Growth. Johns Hopkins University Press.

Ford, A. G. 1962. The Gold Standard 1880-1914: Britain and Argentina. Oxford: Clarendon Press.

Friedman, Milton, and Anna Jacobson Schwartz. 1963. A Monetary History of the United States 1867-1960. Princeton University Press.

Furman, Jason, and Joseph Stiglitz. 1998. "Economic Crises: Evidence and Insights from East Asia.” BPEA, 2: 1998, 1-114. 
Gerschenkron, Alexander. 1962. Economic Backwardness in Historical Perspective. Harvard University Press.

Goldstein, Morris. 1998. The Asian Financial Crisis: Causes, Cures, and Systemic Implications. Policy Analyses in International Economics 55. Washington: Institute for International Economics.

Greenspan, Alan. 1998. “Question: Is There a New Economy?” Remarks at the Haas Annual Business Faculty Research Dialogue, University of California, Berkeley, Haas School of Business, September 4, 1998. Accessed on the Federal Reserve Board's World Wide Web site.

Grossman, Richard, and J. Bradford DeLong. Forthcoming. "The Workings of the British Stock Market Before World War I." Unpublished paper. University of California, Berkeley.

Josephson, Matthew. 1934. The Robber Barons. New York: Harcourt, Brace.

Jue, Jaime. 1999. "Interregional Trade and Market Integration: California and the Transcontinental Railroad, 1860-1900.” Ph.D. dissertation, University of California, Berkeley.

Krugman, Paul. 1979. “A Model of Balance-of-Payments Crises.” Journal of Money, Credit, and Banking 11(3): 311-25.

—. 1996. "Are Currency Crises Self-Fulfilling?” In NBER Macroeconomics Annual 1996, edited by Ben Bernanke and Julio Rotemberg. MIT Press.

Lewis, Arthur. 1978. The Evolution of the International Economic Order. Princeton University Press.

Lewis, Oscar. 1938. The Big Four: The Story of Huntington, Stanford, Hopkins, and Crocker, and of the Building of the Central Pacific. New York: Knopf.

Maddison, Angus. 1995. Monitoring the World Economy, 1820-1992. Paris: Organization for Economic Cooperation and Development.

Marichal, Carlos. 1989. A Century of Debt Crisis in Latin America: From Independence to the Great Depression, 1820-1930. Princeton University Press.

O'Rourke, Kevin, and Jeffrey Williamson. 1999. Globalization and History: The Evolution of a Nineteenth-Century Atlantic Economy. MIT Press.

Radelet, Steven, and Jeffrey Sachs. 1998. "The Onset of the East Asian Financial Crisis.” Working Paper 6680. Cambridge, Mass.: National Bureau of Economic Research (August).

Riegel, Robert Edgar. 1926. The Story of the Western Railroads: From 1852 Through the Reign of the Giants. New York: Macmillan.

Romer, Christina. 1986. "Spurious Volatility in Historical Unemployment Data." Journal of Political Economy 94(1): 1-37.

Sachs, Jeffrey. 1998. "The IMF and the Asian Flu.” American Prospect 37 (MarchApril): 16-21.

Sinn, Gerlinde, and Hans-Werner Sinn. 1992. Jumpstart: The Economic Unification of Germany. MIT Press. 
Sprague, O. M. W. 1910. History of Crises Under the National Banking System. Washington: Government Printing Office.

Taylor, Alan. 1996. "International Capital Mobility in History: The SavingInvestment Relationship.” Working Paper 5743. Cambridge, Mass.: National Bureau of Economic Research (September).

U.S. Congress. 1873. Report of the Select Committee to Investigate the Alleged Credit Mobilier Bribery. House Reports 77, 42nd Congress, 3d session. Washington: Government Printing Office.

Vernon, Raymond. 1971. Sovereignty at Bay: The Multinational Spread of U.S. Enterprises. New York: Basic Books. 